\title{
PATTERNS OF HUMAN OCCUPATION DURING THE EARLY HOLOCENE IN THE CENTRAL EBRO BASIN (NE SPAIN): A RESPONSE TO THE 8200-YR B.P. CLIMATIC EVENT
}

\author{
P. González-Sampériz ${ }^{1 *}$; P. Utrilla ${ }^{2}$; C. Mazo ${ }^{2}$; B. Valero-Garcés ${ }^{1}$; MC. Sopena ${ }^{2}$; \\ M. Morellón ${ }^{1}$; M. Sebastián ${ }^{2}$; A. Moreno ${ }^{1} \&$ M. Martínez-Bea ${ }^{2}$ \\ ${ }^{1}$ Instituto Pirenaico de Ecología-CSIC, Avda. Montañana 1005, Apdo 202, 50080 Zaragoza, \\ Spain; ${ }^{2}$ Dpto. de Ciencias de la Antigüedad (Prehistoria), Universidad de Zaragoza, C/ Pedro Cerbuna \\ 12, 50009 Zaragoza, Spain, \\ * Author for correspondence (e-mail: pgonzal@ipe.csic.es)
}

\begin{abstract}
The Central Ebro River Basin (NE Spain) is the most northern area of truly semi-arid Mediterranean climate in Europe and prehistoric human occupation has been strongly influenced by these unique environmental conditions. The Bajo Aragón region (SE Ebro River Basin) was intensively populated during the Early Holocene (9400 $8200 \mathrm{cal}$. yr B.P.) but the settlements were abandoned abruptly at around $8200 \mathrm{cal}$. yr B.P. Modern climate conditions single out this region due to the harsh environment, characterized by the highest absolute summer temperatures of the Ebro River Basin. We propose that this "archaeological silence" was caused by the regional impact of the global abrupt 8.2 ka cold event. Available regional paleoclimate archives demonstrate the existence of an aridity crisis 8200 years ago that interrupts the humid Early Holocene. That environmental crisis would have forced hunter-gatherers groups from the Bajo Aragón to migrate to regions with more favourable conditions (i.e. more humid mountainous areas) and only return in the Neolithic. Coherently, archaeological sites persist during this crisis in the nearby Iberian Range (Maestrazgo) and the North Ebro River area (Pre-Pyrenean mountains and along the northwestern Ebro Basin).

Keywords: Abrupt climate change, Central Ebro River Basin, Holocene, Migration, Hunter-Gatherers, Aridity, Archaeology.
\end{abstract}




\section{Introduction}

Prehistoric and historic societies around the world, particularly those located in semi-arid areas, have been highly vulnerable to abrupt climatic changes, with numerous examples of widespread abandonment, migrations and even cultural collapses. For example, the Eastern Sahara occupation during the Holocene humid period: Hoelzmann et al., 2001; the Neolithic migrations that occurred in Europe: Turney and Brown, 2007 and the population decreases in the North American Great Plains during the Altithermal period of the Middle Holocene: Meltzer, 1999. In several cases, environmental crises caused by increased aridity have been considered a main trigger in civilization collapse, as the Akkadian Empire, the Argaric Culture and the Maya Civilization, although other possible socio-economic factors have also been considered: Cullen et al., 2000, Carrión et al., 2007; Haug et al., 2003, respectively. The Ebro River Valley (NE Spain) has a long history of human occupation (Utrilla, 2002; Montes et al., 2006) and because of the harsh environmental conditions that characterize this Mediterranean area it provides several examples of the complex interplay of climate and human societies. In addition, this region includes the Bajo Aragón area, an ecologically “fragile” area characterized by a strong water deficit (López-Martín et al., 2007).

The Holocene (last $11.5 \mathrm{ka}$ ) has been classically considered a climatically stable episode, especially when compared with the last glacial period. However, there is increasing evidence of significant climate variability at suborbital scales during the present interglacial at a global scale (Mayewski et al., 2004). In the Iberian Peninsula several sites document large climate variability during the Holocene and particularly the strong impact in vegetation communities and hydrology during the Early Holocene (Ramil-Rego et al., 1998; Sanchez-Goñi and Hannon, 1999; Carrión, 2002; Pla and Catalán, 2005; González-Sampériz et al., 2006; Davis and Stevenson, 2007; Morellón et al., 2008).

The 8.2 ka event is one of the most significant climate crisis of the last 11.5 kyrs and was globally identified as a short cold an arid period (Alley and Agustsdottir, 2005; Rohling and Pälike, 2005). This event appears to have been generally cooler over much of the Northern Hemisphere, and it is also characterized by: i) a widespread aridity in low latitudes (de Menocal et al., 2000; Gasse and Van Campo, 1994); ii) enhanced seasonality (Baldini et al., 2002); and iii) dry northerly winds influence in the western Mediterranean (Frigola et al., 2007). Although many new paleoclimate records have contributed to reconstruct the climate variability associated to this event (see 
compilation in Mayewski et al., 2004), the forcing mechanisms remain under discussion (Bauer et al., 2004; Rohling and Pälike, 2005). Global climate models (GCM) show that colder conditions in the north Atlantic would translate into more arid conditions in the continental areas of the Mediterranean region, including the Iberian Peninsula (Wiersma and Renssen, 2006). In this sense, it is not difficult to imagine how ecosystems could have been easily destabilized in the Central Ebro Basin during short climate crises, with great consequences for the already scarce vegetation, fauna and humans during the Prehistory.

In this paper we present a detailed compilation of the radiocarbon -dated settlements located in the Ebro Basin between 11.5 - 6.5 cal ka B.P. and analyze the relationship between their occupation patterns and the climate evolution reconstructed from available regional palaeoenvironmental sequences. Our results point to the cal. 8.2 ka arid event (Alley et al., 1997) as the main cause for the dramatic cessation of the use of the sites identified at the Bajo Aragón during the end of the Epipaleolithic or Mesolithic culture. The region will not be re-occupied intensively until the beginning of the Neolithic, when a new economic activity (agriculture, pastoralism) would allow the subsistence in this particular region.

\section{Present-day environment: climate and vegetation}

The climate in the Central Ebro River Basin is Mediterranean with strong continental influences resulting in very hot summers, cold and relatively dry winters, strong dry NW winds and low rainfall due to the rain-shadow effect of the Iberian Range (Capel Molina, 1981; García-Vera, 1996). Specifically, this region is the northernmost region of truly semi-arid climate in Europe. In fact, the Bajo Aragón area shows the maximum absolute temperatures in the area with more than $45^{\circ} \mathrm{C}$ (López Martín et al., 2007) next to the greatest evapotranspiration index of the region with an annual water deficit of more than $800 \mathrm{~mm}$ and only $300 \mathrm{~mm}$ of annual precipitation (Fig.1).

The present landscape in the Central Ebro Basin (including the Bajo Aragón) is an herbaceous-shrubly land, mostly dedicated to agriculture. Steppe vegetation cover is generally open, leaving small patches with xerophyte shrubs, Pinus halepensis, Quercus coccifera and Juniperus thurifera as the main arboreal taxa. Nitrophilous and gypsophilous plants are also abundant (Molero et al., 1986; Longares, 1997). In contrast, the North Ebro area sustains forested landscapes dominated by conifers (Abies 
alba, Pinus uncinata, Pinus sylvestris) or broad-leaf angiosperms (Quercus pubescens, Quercus robur, Fagus, Corylus, Betula, Acer, Tilia, Sorbus). The Prepyrenean foothills (southeastern of the North Ebro area) and the Iberian Range (Maestrazgo) have a more Mediterranean influence and vegetation is dominated by diverse types of conifers depending the altitude and the substrate and Quercus ilex-rotundifolia or Q. fagineapubescens with dense shrub land (Blanco et al., 1997).

\section{Cultural chronology during the Early Holocene}

Archaeological information for the Early Holocene in the Ebro Basin shows important population density only in specific areas (Utrilla, 2002, 2005; Montes et al., 2006). For example, 14 archaeological sites are located in the Bajo Aragón during the period known as "Recent Mesolithic” or "Epipaleolithic Geometric culture” (cal. 9-8 ka B.P.). Despite the high number of settlements known in the whole Ebro Basin, only 40 of them have dated occupation levels between 11-6.5 cal ka B.P. For this study we consider the available radiocarbon dates (228) associated to these 40 sites (Tables 1 and 2 , additional information). The dates have been converted into calendar ages using the calibration curve from CalPal-2007-HULU (Weninger et al., 2007; Weninger \& Jöris, in press).

A diagram with the probability of occupation based on the available dates on eight archaeological sites is shown in Figure 2. The settlements located in the North Ebro (Axoste, Mendandia and ForcasI and II) do not reflect any occupation change around $8000 \mathrm{cal}$ yr B.P. On the contrary, the sites located in the Bajo Aragón (Angel 1 and 2, Los Baños, Botiquería dels Moros and Pontet) were abandoned at this time. The settlement of Mas Nou in Maestrazgo Mountains shows its first occupation just after 8000 cal B.P. Based on this complete archaeological compilation, a large migration of people from the Bajo Aragón to more humid mountain areas occurred at around 8000 cal B.P. (Figs. 3a and 3b).

Although erosion of the archaeological record cannot be ruled out as a factor contributing to the observed "silence", the high number of sites documented in this study, and their location in different geomorphological settings point towards regionalscale processes (migration) more than to site-specific processes (erosion).. Besides, the stratigraphy of the sites represented in Fig. 2 clearly shows that the intervals without human occupation always correspond to archaeologically sterile levels (without industry, fire, fauna or human traces) but not to hiatus (lack of sediment) as a 
consequence of erosion processes. The archaeological levels are always in situ and, in addition, the abandonment is correctly reflected in the stratigraphy because is bounded by fertile archaeological levels at top and bottom layers. So, the inherent problem in archaeology that relates erosion and archaeological material displacement known as “apparent archaeological contexts” (Bernabeu et al., 1999) cannot be applied to this area.

Most of the settlements located in the Bajo Aragón were re-occupied after 700 years (from 7300 cal. yr B.P. on) when the Neolithic culture was well developed in the whole region (Fig.3c). Nevertheless, one site, Botiquería dels Moros shows sporadic occupation at $7670 \mathrm{cal}$. yr B.P., only 500 years after the abandonment of the area. However, the archaeological material found in this level (no pottery, mainly lithic industry) is poor, and the cultural adscription is not clear pointing to a short occupation (only 6-20 cm depth), probably as a knapping site (Utrilla et al., 1998; Barandiarán and Cava, 2000).

\section{Environmental changes during the Early Holocene}

Numerous paleoclimate reconstructions show a more positive water balance in the lakes and an increase in forest formations in NE Spain caused by cool temperatures and / or higher precipitation during the Early Holocene (around 11,500 to 7000 yr B.P.) (Montserrat, 1992; Davis, 1994; Valero-Garcés et al., 2000, 2004; González-Sampériz, 2004a; González-Sampériz et al., 2006, 2008; Davis and Stevenson, 2007; Morellón et al; 2008). Higher lake levels observed throughout the Mediterranean region during this period have also been explained as a result of cooler temperatures and/or higher precipitation (Harrison and Digerfeldt, 1993; Roca and Julià, 1997; Giralt et al., 1999; Reed et al., 2001). The vegetation cover of NE Spain during with the Early Holocene reflects humid conditions: from maximum of mesophytes in the Pyrenees (i.e., Tramacastilla: Montserrat, 1992; El Portalet: González-Sampériz et al., 2006), PrePyrenees (i.e., Peña 14 archaeological site: González-Sampériz, 2004a; Estanya Lake: Morellón et al., 2008), Iberian Range (i.e., Ojos del Tremedal: Stevenson, 2000) and North Ebro (i.e., Velate: Peñalba, 1989) to more extensive Mediterranean forest formations (coniferous and evergreen Quercus) and scarce steppe land proportions in lowlands of the Central Ebro Basin (i.e., La Playa: González-Sampériz et al., 2008).

Several sedimentary sequences have provided local palaeoenvironmental information about the Early Holocene, although none presents a continuous record up to 
the Middle Holocene (Valero-Garcés et al., 2000, 2004; González-Sampériz et al., 2008). Most sequences come from archaeological sites with discontinuous records (López-García, 1992; González-Sampériz, 2004b) or playa-lake sediments where hiati are common (Davis, 1994; Valero-Garcés et al., 2000, 2004; González-Sampériz et al., 2008). In a recent study, Davis and Stevenson (2007) interpret two playa-lake records from Hoya del Castillo (HdC) and Laguna Guallar (LG) (Fig.1) as possible candidates for "sedimentary continuity" and "high resolution" pollen analysis. Although the authors claimed that the dating and the resolution are enough to pinpoint the 8.2 event, the reconstructions are based on only 3 radiocarbon dates from HdC, one from LG, and two tie points based on pollen content (Ephedra curve) without considering the sedimentation rate differences and pollen-sampling resolution (every $4 \mathrm{~cm}$ in LG and every $8 \mathrm{~cm}$ in $\mathrm{HdC}$ ). The chronological model does not seem robust enough to support a centennial scale reconstruction in these playa-lake records. However, in spite of the limitations, playa lake records are in some areas the only palaeoclimatological records, although the difficulties to achieve robust chronologies and the inherent problems related to the sedimentation processes (erosion) greatly hamper the identification of short and abrupt events as the 8.2 cal. ka B.P. (González-Sampériz et al., 2008).

Only regional lacustrine archives of the Ebro River Basin may provide the needed high-resolution reconstructions. Lake Redó (LR), El Portalet (EP) and Estanya Lake (EL) cores represent, at this moment, the only three long sequences in the region (Fig. 1) with a robust chronology based on 10 radiocarbon dates from LR, 13 from EP and 17 from EL and they have been analysed following a multiproxy approach that could show the effects of the 8.2 cal. yr event in climate, palaeohidrology and vegetation at a regional scale (Plá and Catalán, 2005; González-Sampériz et al., 2006; Morellón et al., 2008).

Lake Redó crysophyte cysts altitude anomaly curve shows a warming trend during the Early Holocene interrupted by a cold spell around 8,200 cal yrs B.P. (Plá and Catalán, 2005). Although this event appears embedded in a warm, local fluctuation, the age matches the cold 8.2 event in the GISP2 record (Fig. 4b and 4g). El Portalet pollen record shows a rapid Juniperus response - a decrease in the pollen percentages indicative of more arid conditions- to all abrupt changes identified during the Lateglacial and the Early Holocene, including the 8.2 cal. ka event, (Fig. 4c) (GonzálezSampériz et al., 2006). The mesophytes pollen curve of this site, mainly composed by Betula and Corylus, also reflect a decrease trend after its maximum development during 
the Early Holocene. The Estanya Lake record clearly shows an increase in water availability during the Early Holocene, after 9500 cal. yrs B.P. In addition, an increase in water salinity represented by higher sulphur values (gypsum deposition) (Fig. 4d) occurred around 8200 cal yrs B.P. (Morellón et al., 2008).

Other continental records in Spain also reflect the 8200 cal yr B.P. event. Fluvial deposits in several Iberian watersheds document large floods between ca. 11200-9000 cal. yr B.P. and a period without floods between ca. 8400-7600 cal. B.P. (Benito et al., 2003, Macklin et al., 2006; Thorndycraft and Benito, 2006) in agreement with the more humid conditions of the Early Holocene and the aridity crisis related to the 8.2 event (Fig. 4e).

Available western Mediterranean marine records also show a distinctive Early Holocene signature. The geochemical composition of the IMAGES core (MD99-2343) located offshore Menorca (Balearic Islands), Frigola et al. (2007) points to abrupt events during the Holocene related to the intensity of Mediterranean deep water formation and the amount of particles derived from fluvial transport. The percentage of $\mathrm{K}$ as an indicator of clays transported by the rivers clearly decreases from 9500 to $7700 \mathrm{cal} \mathrm{yr}$ B.P., reaching the minimum at the 8.2 ka event (Fig 4f). In addition, the $\mathrm{Si} / \mathrm{Al}$ ratio, considered a proxy for deep currents intensity, marks the most prominent peak of the last 11 kyrs at the 8.2 ka event (Fig. 4f).

Therefore, the globally cold 8.2 ka event (GISP2 ice core, Fig. 4e) appears in northeastern Spain as a cold short phase in altitude (LR) but as a dry event in most records from the whole studied area (EP, EL, MD99-2343).

\section{Climate and Humans during the 8.2 event in the Central Ebro Basin}

Abrupt climate changes conducive to large changes in water availability have caused a concomitant reduction of archaeological sites in several regions. Thus, Lateglacial and Holocene human occupation of the Puna de Atacama Desert in Chile follows the alternation of dry / wet periods (Núñez et al., 2002). Particularly significant is the "silencio arqueológico", a period without human occupation that has been related to the well-documented Mid Holocene aridity crisis in the Chilean Altiplano (Grosjean et al., 2005). In Europe, the transition between the Bronze-Iron Age in the Netherlands was associated to a cold and humid period around 2650 yr B.P. that also caused an important migration to higher altitudes due to the expansion of wetlands in low areas (van Geel et al., 1996). 
In the Bajo Aragón the influence of climatic conditions on the human occupation appears as a very plausible explanation for the 'archaeological silence' between 80007300 cal. yrs B.P. Contrarily to this situation, the settlements located in the North Ebro persisted, likely due to more favourable conditions. In addition, new occupations occur in the Maestrazgo area at about this time (Olaria et al., 2005; Fernández-López de Pablo, 2006) supporting the hypothesis that Bajo Aragón hunter-gatherers migrated to more humid habitats in the southern Iberian Range mountains. The existence of an exclusive style of "Levantine rock art" in the Maestrazgo, that it is exactly the same than in the Bajo Aragón (Utrilla, 2005; Utrilla \& Martínez Bea, 2006), supports the migration and cultural connections from both areas.

The Bajo Aragón would be definitively re-occupied during the Neolithic, after 7300 cal. yr B.P. The new Neolithic Culture permits a better "adaptation” to the ecologically fragile environment with the use of fire and deforestation practices to facilitate agriculture expansion and grazing. However, despite the proliferation of settlements overall the Ebro Basin, population density in the Bajo Aragón was lower than during the Early Holocene.

\section{Conclusions}

Following a dramatic abandonment of archaeological settlements in the Bajo Aragón (NE Spain), people migrated to more humid areas (North Ebro and Maestrazgo) between ca. 8.190-7.670 cal. ka B.P. The reduced extent of human settlements around 8000 cal. yr B.P. is synchronous with the sharp transition from wet-temperate to more arid climate identified as the 8.2 cal. ka B.P. event. The impact of this short and abrupt climate change in the population of these environmental fragile areas was large enough to cause the abandonment of the region till Neolithic times. This collapse of widespread occupation ("archaeological silence”) reflects environmental stress and likely caused human migrations, changes in habitat types and in the economy. An important decrease in water availability affected the vegetation resources and implied the subsequent animal migration, basis for the hunter-gatherer type of life. During that time, people occupied alternative habitats considered as ecological refuges where appropriate resources for them remained available in the overall harsh environment.

As in other historic or prehistoric times in different geographic locations, this period of abrupt climate change occurred during the Early Holocene forced the hunter- 
gatherer human communities of the central Ebro Basin to look for new habitat areas and to change their subsistence patterns and culture.

\section{Acknowledgements}

This work was part of the projects: "Palinología y Paleoclima: Cambios Climáticos y/o Antropogénicos y Evolución de la vegetación” funded by CSIC (Programa Intramural 2007-2008); “Los cambios climáticos abruptos y su influencia en los ecosistemas y las sociedades humanas en el Pirineo central y occidental" funded by the Aragón Regional Government (DGA) and two projects funded by the Spanish InterMinistry Commission of Science and Technology (CICYT): "Cambios climáticos rápidos en la Peninsula Ibérica basados en calibración de indicadores, series instrumentales largas y análisis de alta resolución de registros lacustres (Subproyecto CGL2006-13327-C04-01/CLI)" and "Cazadores-Recolectores del valle del Ebro (HUM 2005-02882)”. A. Moreno, M. Morellón, M. Sebastián and MC. Sopena have benefited from a Marie Curie Outgoing International Fellowships (proposal 021673IBERABRUPT), a DGA fellowship, a FPI fellowship and a FSE-MEC contract, respectively.

\section{References}

Alley, R.B., Agustsdottir, A.M., 2005. The 8k event: Cause and Consequences of a major Holocene abrupt climate change. Quaternaty Science Reviews 24,11231149.

Alley, R. B., Mayewski, P. A., Sowers, T., Stuiver, M., Taylor, K. C., Clark, P. U., 1997. Holocene climatic instability: A prominent, widespread event 8200 yr ago. Geology 25, 483-486.

Baldini, J.U.L., McDermott, F., Fairchild, I.J., 2002. Structure of the 8200-year cold event revealed by a speleothem trace element record. Science 296, 2203-2206.

Barandiarán, I., Cava, A., 2000. A propósito de unas fechas del Bajo Aragón: reflexiones sobre el Mesolítico y el Neolítico en la Cuenca del Ebro. SPAL 9, 293-326.

Bauer, E., Ganopolski, A., Montoya, M., 2004. Simulation of the cold climate event 8200 years ago by meltwater outburst from Lake Agassiz. Paleoceanography 19, doi:10.1029/2004PA001030. 
Benito, G., Sopeña, A., Sánchez-Moya, Y., Machado, M.J., Pérez-González, A., 2003. Palaeoflood record of the Tagus River (central Spain) during the Late Pleistocene and Holocene. Quaternary Science Reviews 22, 1737- 1756.

Bernabeu, J; Pérez Ripoll, M., Martinez-Valle, R., 1999. Huesos, neolitización y contextos arqueológicos aparentes. Saguntum Extra 2, 69-81.

Blanco, E., Casado, M., Costa, M., Escribano, R., García Antón, M., Génova, M., Gómez, A., Moreno, J., Morla, C., Regato, P., Sainz Ollero, H., 1997. Los bosques ibéricos. Una interpretación geobotánica. Planeta Ed.. Barcelona, 572 pp.

Capel Molina, J.J., 1981. Los climas de España. Oikos-Tau editions, Barcelona, 429 pp. Carrión, J.S., 2002. Patterns and processes of Late Quaternary environmental change in a montane region of southwestern Europe. Quaternary Science Reviews 21, 2047-2066.

Carrión, J.S., Fuentes, N., González-Sampériz, P., Sánchez Quirante, L., Finlaysson, C., Fernández, S., Andrade, A., 2007.Holocene environmental change in a montane region of southern Europe with a long history of human settlement. Quaternary Science Reviews 26, 1455-1475.

Cullen, H.M., deMenocal, P.B., Hemming, S., Hemming, G., Brown, F.H., Guilderson, T., Sirocko, F., 2000. Climate change and the collapse of the Akkadian empire: evidence from the deep sea. Geology 28 (4), 379-382.

Davis, B.A.S., 1994. Palaeolimnology and Holocene environmental change from endorheic lakes in the Ebro Basin, north-east Spain, Ph. D. Thesis, University of Newcastle upon Tyne, 317 pp.

Davis, B.A.S., Stevenson, A.C., 2007. The 8.2 ka event and the Early-Mid Holocene forest, fires and flooding in the Central Ebro Desert, NE Spain. Quaternary Science Reviews 26, 1695-1712.

de Menocal, P., Ortiz, J., Guilderson, T., Sarnthein, M., 2000. Coherent high-and-lowlatitude climate variability during the Holocene Warm Period. Science 288, 2198-2202.

Fernández-López de Pablo, J., 2006. Contribución al conocimiento de la secuencia arqueológica y el habitat del Holoceno Inicial en el Maestrazgo. Saguntum 38, 23-47. 
Frigola, J., Moreno, A., Cacho, I., Canals, M., Sierro, F.J., Flores, J.A., Grimalt, J.O., Hodell, D.A., Curtis, J.H., 2007. Holocene climate variability in the western Mediterranean region from a deepwater sediment record, Paleoceanography 22, PA2209, doi:10.1029/2006PA001307.

García-Vera, M.A., 1996. Hidrogeología de zonas endorreicas en climas semiáridos.

Aplicación a Los Monegros (Zaragoza y Huesca). Diputación General de Aragón, Zaragoza, 297 pp.

Gasse, F., Van Campo, E., 1994. Abrupt post-glacial climate events in West Asia and North Africa monsoon domains. Earth and Planetary Science Letters 126, 435456.

Giralt, S., Burjachs, F., Roca, J. R., Julià, R., 1999. Late Glacial to Early Holocene environmental adjustment in the Mediterranean semi-arid zone of the Salines playa-lake (Alicante, Spain). Journal of Paleolimnology 21, 449-460.

González-Sampériz, P., 2004a. Evolución paleoambiental del sector central de la cuenca del Ebro durante el Pleistoceno superior y Holoceno. Instituto Pirenaico de Ecología-CSIC, Zaragoza, 210 pp.

González-Sampériz, P., 2004b. Análisis palinológico del yacimiento de Los Baños de Ariño (Teruel). In: Utrilla, P., Rodanés, J.M. (Eds.), El yacimiento arqueológico de Los Baños de Ariño. Monografías Arqueológicas, Zaragoza, pp. 59-62.

González-Sampériz, P., Valero-Garcés, B.L., Moreno, A., Jalut, G., García-Ruiz, J.M., Martí-Bono, C., Delgado-Huertas, A., Navas, A., Otto, T., Dedoubat, J.J., 2006. Climate variability in the Spanish Pyrenees during the last 30,000 yr revealed by the El Portalet sequence. Quaternary Research 66, 38-52.

González-Sampériz, P., Valero-Garcés, B. L; Moreno, A; Morellón, M; Navas, A; Machín, J., Delgado-Huertas, A., 2008. Vegetation changes and Hydrological fluctuations in the Central Ebro Basin (NE Spain) since the Lateglacial: saline lake records. Palaeogeography, Palaeoclimatology, Palaeoecology 259, 157-181.

Grootes, P., Stuiver, M., 1997. Oxygen 18/16 variability in Greenland snow and ice with 103-to 105-year time resolution. Journal of Geophysical Research 102, 26455-26470.

Grosjean, M., Núñez, L., Cartajena, I., 2005. Palaeoindian occupation of the Atacama Desert, northern Chile. Journal of Quaternary Science 20, 643-653.

Harrison, S. P., Digerfeldt, G., 1993. European lakes as palaeohydrological and palaeoclimate indicators. Quaternary Science Reviews 12, 233-248. 
Haug, G.H., Ganther, D., Peterson, L.C., Sigman, D.M., Hughen, Y.R., Aeschlimann, B., 2003. Climate and the collapse of Maya civilization. Science 299, 17311735.

Hoelzmann, P., Keding, B., Berke, H., Kröpelin, S., Kruse, H. J., 2001. Environmental change and archaeology: lake evolution and human occupation in the Eastern Sahara during the Holocene. Palaeogeography, Palaeoclimatology, Palaeoecology 169, 193-217.

Longares, L.A., 1997. El paisaje vegetal en el entorno de la Reserva Ornitológica "El Planerón” (belchite, Zaragoza). Consejo de Protección de la NaturalezaSEO/Birdlife. Serie Investigación 7, Zaragoza, 195 pp.

López-Martín, F., Cabrera, M., Cuadrat, J.M., 2007. Atlas Climático de Aragón. Departamento de Medio Ambiente. Gobierno de Aragón, Zaragoza, 222 pp.

López-García, P., 1992. Análisis polínicos de cuatro yacimientos arqueológicos situados en el Bajo Aragón. Aragón / Litoral Mediterráneo. Intercambios culturales durante la Prehistoria. Institución Fernando el Católico. Universidad de Zaragoza, pp. 235-242.

Macklin, M.G., Benito, G., Gregory, K.J., Johnstone, E., Lewin, J., Michczynska, D.J., Soja, R., Starkel, L., Thorndycraft, V.R., 2006. Past hydrological events reflected in the Holocene fluvial record of Europe. Catena 66, 145-154.

Mayewski, P.A., Rohling, E.E., Stager, J.C., Karlen, W., Maasch, K.A., Meeker, L.D., Meyerson, E.A., Gasse, F., Kreveld, S.v., Holmgren, K., Lee-Thorp, J., Rosqvist, G., Rack, F., Staubwasser, M., Schneider, R.R., Steig, E.J., 2004. Holocene climate variability. Quaternary Research 62, 243-255.

Meltzer, D.J., 1999. Human responses to Middle Holocene (Altithermal) climates on the Nort American Great Plañís. Quaternary Research 52, 404-416.

Molero, J., Blanché i Vergés, C. 1986. Las cubetas arreicas al sur de Bujaraloz (Valle del Ebro). Contribución a su estudio fitocenológico. Lazaroa 9, 277-300.

Montes, L ; Utrilla, P., Mazo, C., 2006. El epipaleolítico macrolítico en Aragón en su contexto del valle del Ebro y Cataluña costera. In: Alday, A., (ed.), Simposio trans-regional sobre el Mesolítico de la Cuenca del Ebro y Litoral Mediterráneo. Memorias de yacimientos alaveses, 11. Vitoria, pp. 189-218.

Montserrat, J., 1992. Evolución glaciar y postglaciar del clima y la vegetación en la vertiente sur del Pirineo: estudio palinológico. Monografías del Instituto Pirenaico de Ecología-CSIC, Zaragoza, 147 pp. 
Morellón, M., Valero-Garces, B., Moreno, A., Gonzalez-Samperiz, P., Mata, P., Romero, O., Maestro, M., Navas, A., 2008. Holocene palaeohydrology and climate variability in Northeastern Spain: The sedimentary record of Lake Estanya (Pre-Pyrenean range). Quaternary International 181, 15-31.

Núñez, L., Grosjean, M., Cartajena, I., 2002. Human occupations and climate change in the Puna de Atacama, Chile. Science 298, 821-824.

Olaria, C; Gusi, F., Gómez, J.L., 2005. Un enterramiento Meso-Neolítico en el Cingle del Mas Nou (Ares del Maestre, Castellón) del 7000B.P. en territorio de arte levantino. III Congreso de Neolítico de la Península Ibérica. Santander, pp. 615623.

Peinado-Lorca, M., Rivas-Martínez, S., (Eds)., 1987. La vegetación de España. Colección Aula Abierta, 515 pp.

Peñalba, C., 1989. Dynamique de la végétation tardiglaciare et holocène du centre-nord de l'Espagne d'après l'analyse pollinique. Université d'Aix-Marseille. Tesis Doctoral, 190 pp.

Plá, S., Catalan, J., 2005. Chrysophyte cysts from lake sediments reveal the submillennial winter/spring climate variability in the northwestern Mediterranean region throughout the Holocene. Climate dynamics 24, 263-278.

Ramil-Rego, P., Muñoz-Sobrino, C., Rodríguez-Guitán, L., Gómez-Orellana, L., 1998. Differences in the vegetation of the North Iberian Peninsula during the last 16,000 years. Plant Ecology 138, 41-62.

Reed, J.M., Stevenson, T., Juggins, S., 2001. A multi-proxy record of Holocene climatic change in southwestern Spain: the Laguna de Medina, Cádiz. The Holocene 11, 707-719.

Roca, J.R., Julià, R., 1997. Lae Glacial and Holocene climatic changes and desertification expansion based on biota content in the Salines séquense, Southeastern Spain. Geobios 30, 823-830.

Rohling, E.J., Pälike, H., 2005. Centennial-scale climate cooling with a sudden cold event around 8,200 years ago. Nature 434, 975-979.

Sánchez-Goñi, M.F., Hannon, G., 1999. High-altitude vegetational pattern on the Iberian Mountain Chain (north-central Spain) during the Holocene. Holocene 9, 39-57.

Stevenson, A., 2000. The Holocene forest history of the Montes Universales, Teruel, Spain. Holocene 10, 603-610. 
Thorndycraft, V. R., Benito, G., 2006. The Holocene fluvial chronology of Spain: evidence from a newly compiled radiocarbon database. Quaternary Science Reviews 25, 223-234.

Turney, C.S.M., Brown, H., 2007. Catastrophic early Holocene sea level rise, human migration and the Neolithic transition in Europe. Quaternary Science Reviews 26, 2036-2041.

Utrilla, P., 2002. Epipaleoliticos y Neolíticos en el Valle del Ebro. The Neolithic Landscapes of the Mediterranean. Saguntum Extra 5, 179-208.

Utrilla, P., 2005. Arte rupestre en Aragón. 100 años después de Calapatá. In: Hernández, M., Soler, J., (Eds.). Arte rupestre en la España mediterránea. Alicante, pp. 341-378.

Utrilla, P., Martinez-Bea, M., 2006. Arte levantino y territorio en la España mediterránea. Clío Arqueológica 20, 17-52.

Utrilla, P., Cava, A., Alday, A., Baldellou, V., Barandiarán, I., Mazo, C., Montes, L., 1998. Le passage du mésolithique au néolithique ancien dans le Bassin de l'Ebre (Espagne) d'après les datations C14. Préhistoire Européenne vol.12, 171-194.

Valero-Garcés, B., González-Sampériz, P., Delgado-Huertas, A., Navas, A., Machín, J., Kelts, K., 2000. Lateglacial and Late Holocene environmental vegetational change in Salada Mediana, central Ebro Basin, Spain. Quaternary International 73/74, 29-46.

Valero-Garcés, B.L, González-Sampériz, P., Navas, A., Machín, J., Delgado-Huertas, Peña-Monne, J.L., Sancho-Marcén, C., Stevenson, A., Davis, B.A.S., 2004. Paleohydrological fluctutations and steppe vegetation during the last glacial maximum in the Central Ebro valley (N.E. Spain). Quaternary International 122, 43-55.

Van Geel, B; Buurman, J., Waterbolk, H., 1996. Archaeological and palaeoecological indications of an abrupt climate change in The Netherlands, and evidence for climatological teleconnections around 2650 BP. Journal of Quaternary Science 11 (6), 451-460.

Weninger, B., Jöris, O. (in press). Towards an Absolute Chronology at the Middle to Upper Palaeolithic Transition in Western Eurasia: A New Greenland Time-scale Based on U/Th Ages. Journal of Human Evolution (in press).

Weninger, B., Jöris, O., Danzeglocke, U., 2007. CalPal-2007. Cologne Radiocarbon Calibration \& $\underline{\text { Palaeoclimate Research Package. http://www.calpal.de/ }}$ 
Wiersma, A.P; Renssen, H., 2006. Model-data comparison for the 8.2 ka B.P. event: confirmation of a forcing mechanism by catastrophic drainage of Laurentide Lakes Quaternary Science Reviews 25, 63-88. 


\section{Figure captions}

Fig.1. A) Location map of the Ebro Basin with all the archaeological settlements (dots) and palaeoenvironmental sites (stars) cited in the text. Currently, the Bajo Aragón area has a harsh continental climate with: B) the highest absolute maximum temperatures of Aragón region (included in the Ebro Basin), reaching more than $45^{\circ} \mathrm{C}$ in summer; and C) one of the three highest evapotransipration index areas of the Iberian Peninsula (more than 800 mm). The Bajo Aragón area is encircled in Fig.1B and C.

Archaeological settlements: 1. Fuente Hoz, 2.Kampanoste, 3. Kampanoste Goikoa, 4. Mendandia, 5. Atxoste, 6. La Peña de Marañón, 7. Peña Larga, 8. Los Cascajos, 9. Cueva Lóbrega, 10. Abauntz, 11. Aizpea, 12. Zatoya, 13.Paternanbidea, 14. Paco Pons, 15. Peña 14,16. Legunova, 17. Chaves, 18. Huerto Raso, 19. Puyascada, 20. Forcas I,21. Forcas II, 22. Balma Margineda, 23. Moro de Olvena, 24. Parco, 25. Moli de Salt,26. Riols, 27. Filador, 28. Costalena, 29. Pontet, 30. Botiquería dels Moros, 31. Vidre, 32. Los Baños, 33. Angel 1, 34. Angel 2, 35. Toros de Cantavieja, 36. Cova de las Bruixes, 37. Cova Fosca, 38. Mas Nou, 39. Cabezo de la Cruz, 40. Cueva del Gato, 41. Lampara, 42. Revilla, 43. Mas Cremat.

Palaeoenvironmental sites: EP: El Portalet, T: Tramacastilla, LR: Lake Redó, EL: Estanya Lake, LG: Laguna Guallar, LP: La Playa, HY: Hoya del Castillo.

Fig.2.- Diagram of calibrated dates for eight selected archaeological sites from North Ebro (Mendandia, Axoste and Forcas) and South Ebro Basin (grouped in Bajo Aragón Ángel, Los Baños, Botiquería dels Moros and Pontet- and Maestrazgo areas -Mas Nou-) between the 11000-6500 cal yr B.P. interval. The setlements of the Bajo Aragón are affected by a dramatic abandonment marked by the band at 8.2 cal ka B.P. referenced at the GISP2 ice core (Grootes and Stuiver, 1997). The Mas Nou site, in the Maestrazgo Mountains (Iberian Range), shows its first occupation when the Bajo Aragón is abandoned.

The fertile (occupation) and sterile (abandoned) archaeological levels of every settlement are also indicated by a grey band below each site. The corresponding cultural adscription is shown at the bottom of the diagram (Ancient Mesolithic: Az- Azilian, Em/SA- Epipalaeolithic microlaminar or Sauveterrian, MD- Mesolithic with Denticulates; Recent Mesolithic: MG-Mesolithic with geometrics; and Neolithic: NAAncient Neolithic). 
Fig.3.- Chronological and cultural periods in the Ebro Basin (modified from Utrilla \& Martínez-Bea, 2006): 3a) between 11000-8200 cal yr B.P. (dense human occupation); 3b) between 8200-7700 cal yr B.P. (abandonment of the Bajo Aragón: “Archaeological Silence"; continuous occupation in North Ebro areas and onset of the occupation in the Maestrazgo Mountains); 3c) between 7700-6500 cal yr B.P. (re-occupation of the Bajo Aragón and new development overall the Ebro Basin).

Fig.4.- Interval 11,500 to 6,500 cal yr B.P. comparison between:

- A) probability curves of Archaeological Occupation (\%) for Northern Ebro Basin, Bajo Aragón and Maestrazgo regions (this study) and

- a suite of regional palaeoenvironmental records: B) LR-Lake Redó record of crysophytes altitude anomaly (meters) (Plá and Catalán, 2005); C) EP-El Portalet Peatbog record Juniperus and Mesophytes pollen percentages (\%) (González-Sampériz et al., 2006); D) EL-Estanya Lake record Sulphur (S) content (counts per second, cps) (Morellón et al., 2008); E) Paleoflood episodes in the Iberian Peninsula (based in Thorndycraft and Benito, 2006); F) Minorca Drift record (Core MD99-2343, Mediterranean Sea) Potassium (K) percentage (\%) and Silicon/Aluminium (Si/Al) ratio (Frigola et al., 2007) and G) Greenland GISP2 ice core oxygen isotope curve (Grootes and Stuiver, 1997).

A grey band marks the $8.2 \mathrm{cal}$ ka B.P. event as referenced at the GISP2 ice core (Grootes and Stuiver, 1997) 
Figure 1.

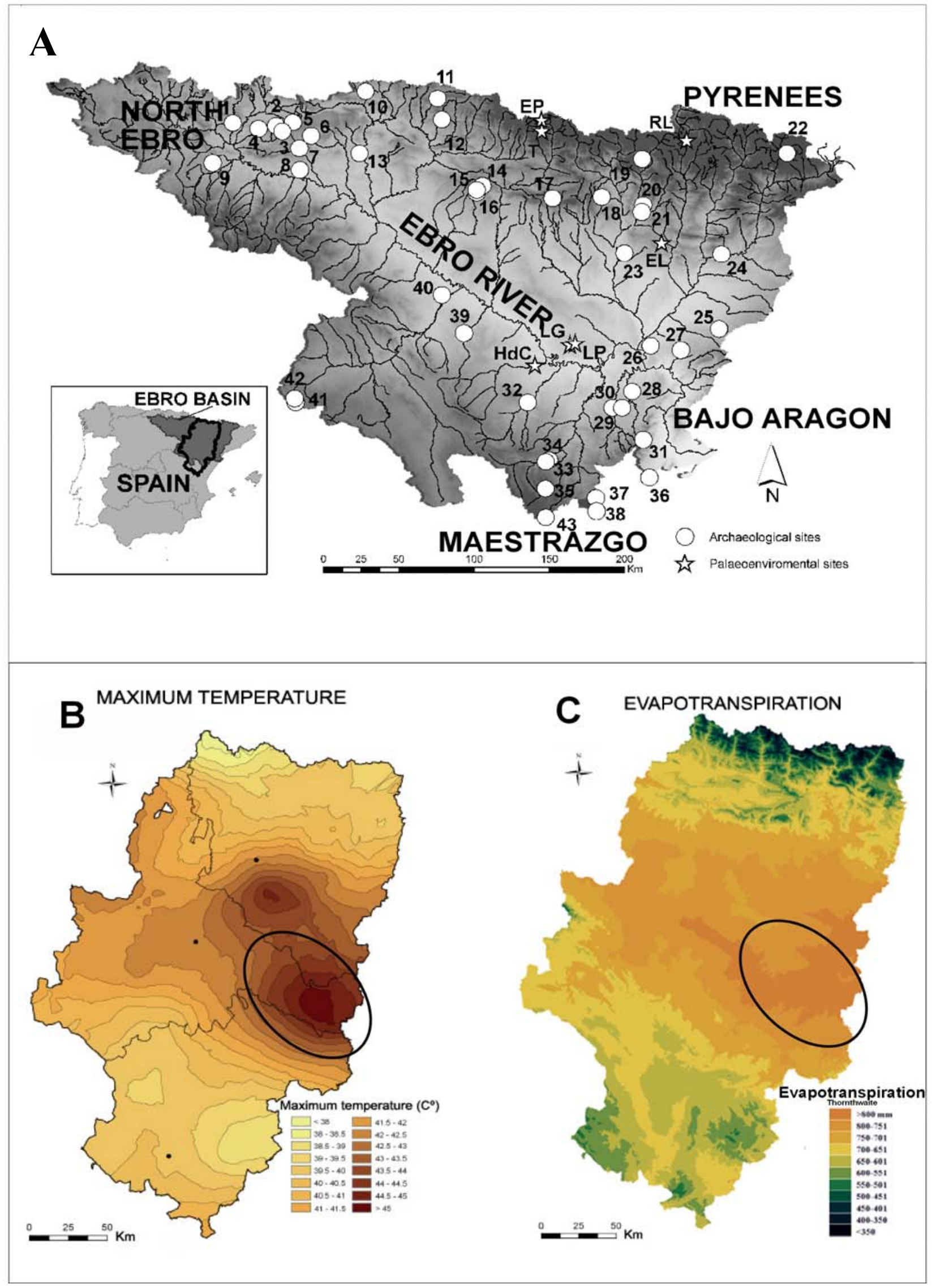


Figure 2.

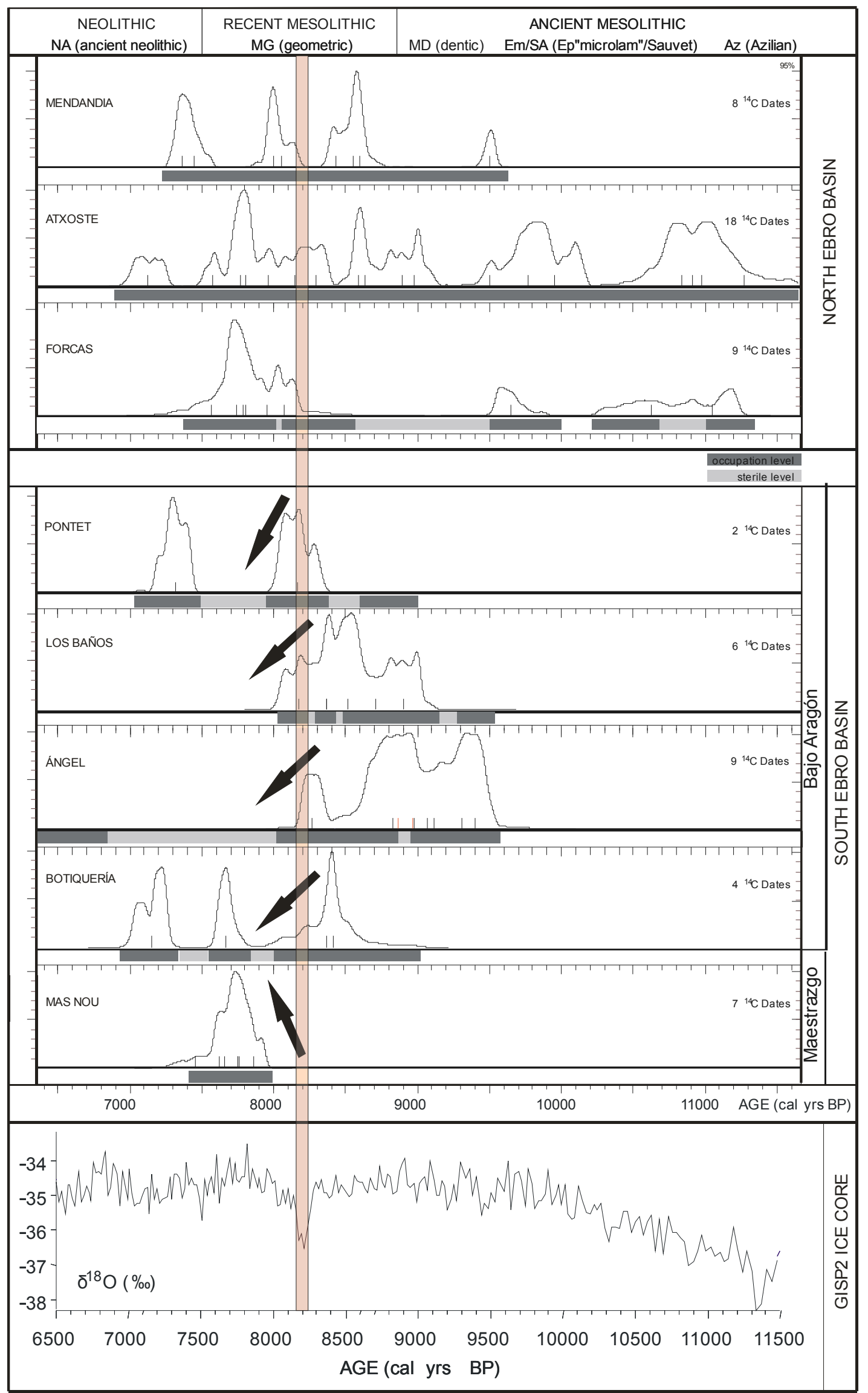


Figure 3.

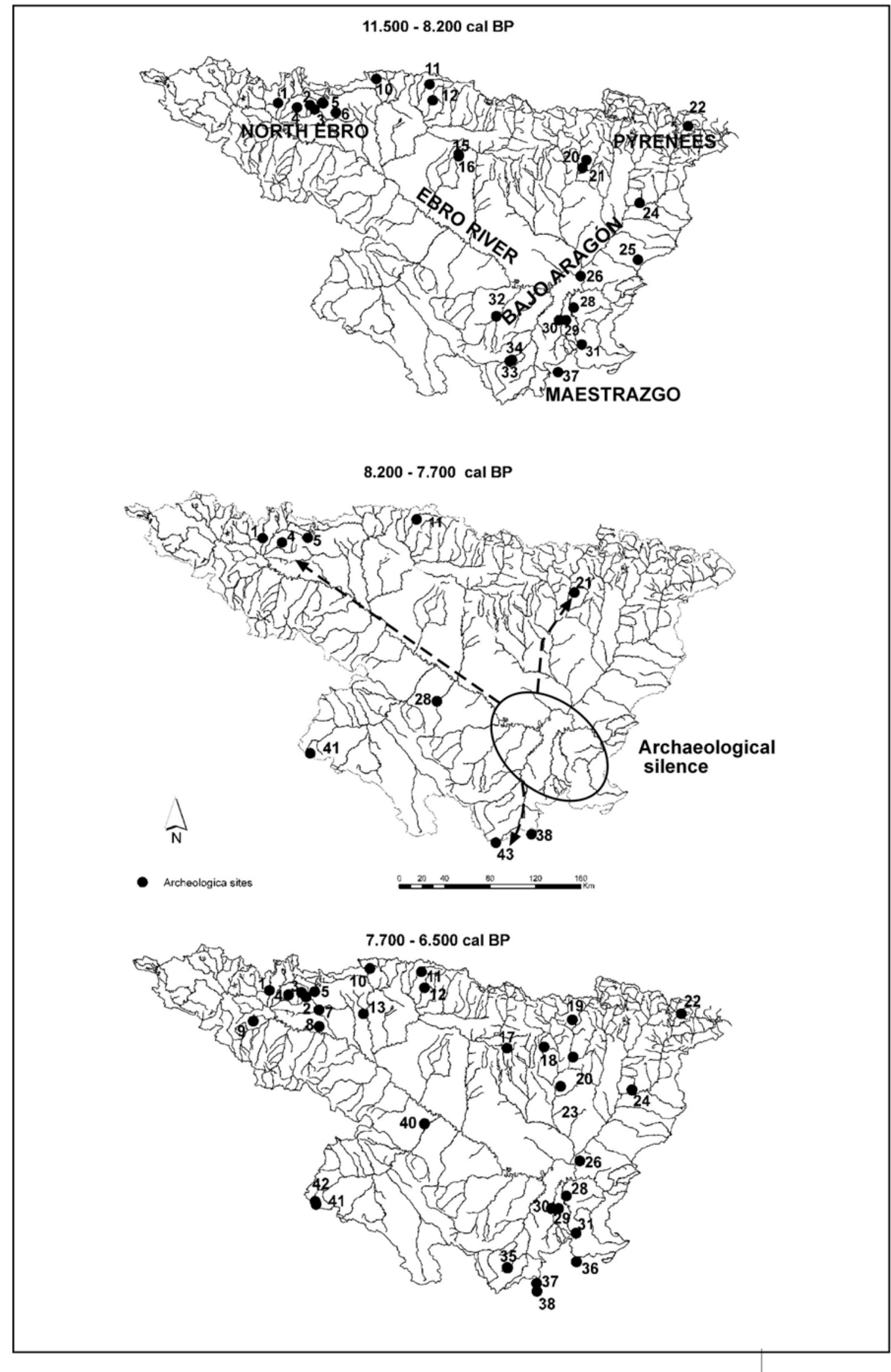




\section{Figure 4.}

A) ARCHAEOLOGICAL SITES

AGE (cal yrs BP)

$6500,7000,7500,8000,8500,9000,9500,10000,10500,1,1000,11500$

$94{ }^{14} \mathrm{C}$ dates $\quad$ North Ebro $\quad 95 \%$

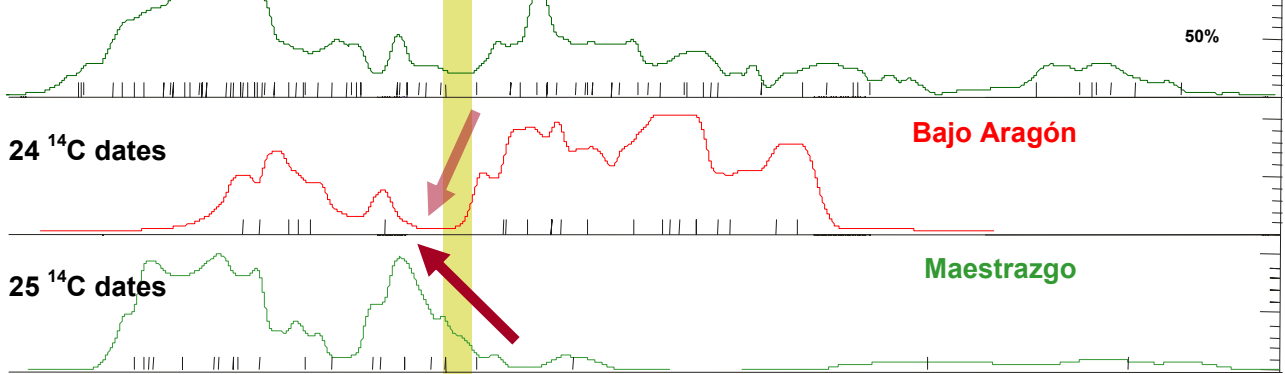

B) LR- LAKE REDÓ
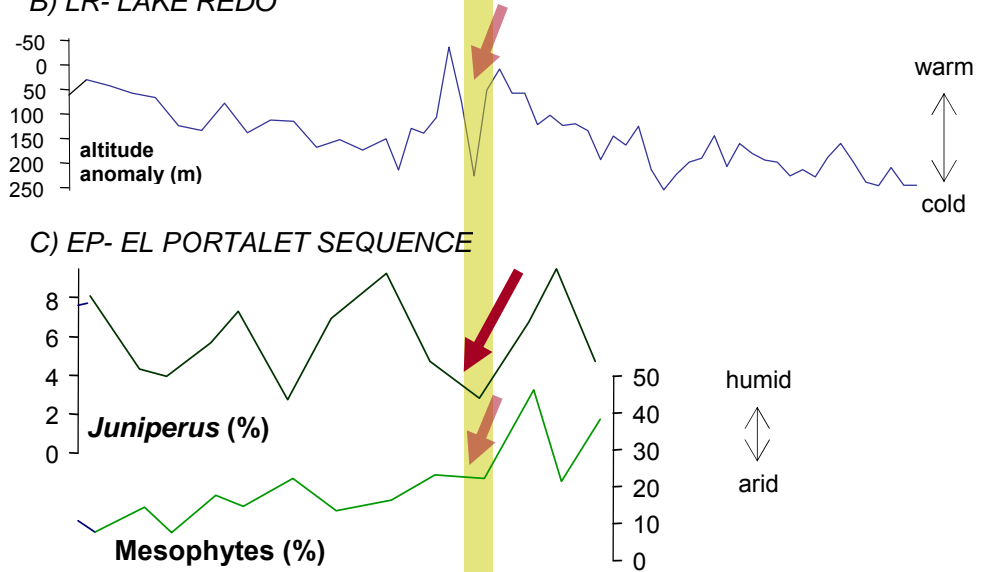

D) EL-ESTANYA LAKE

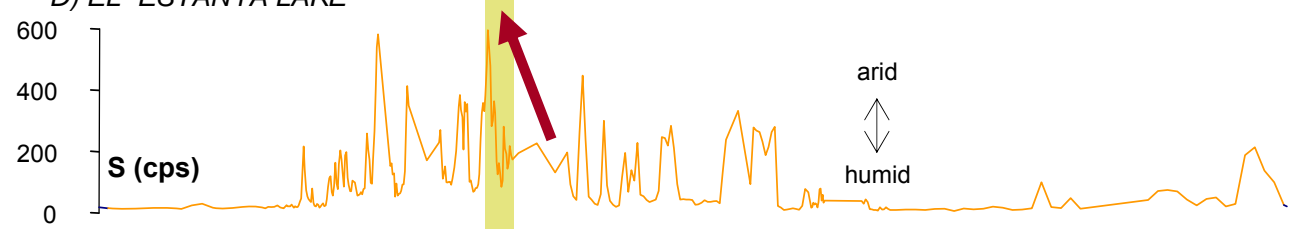

E) PALEOFLOOD EPISODES IN IBERIA

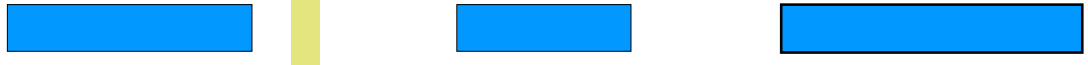

F) W MEDITERRANEAN SEA MD99-2343

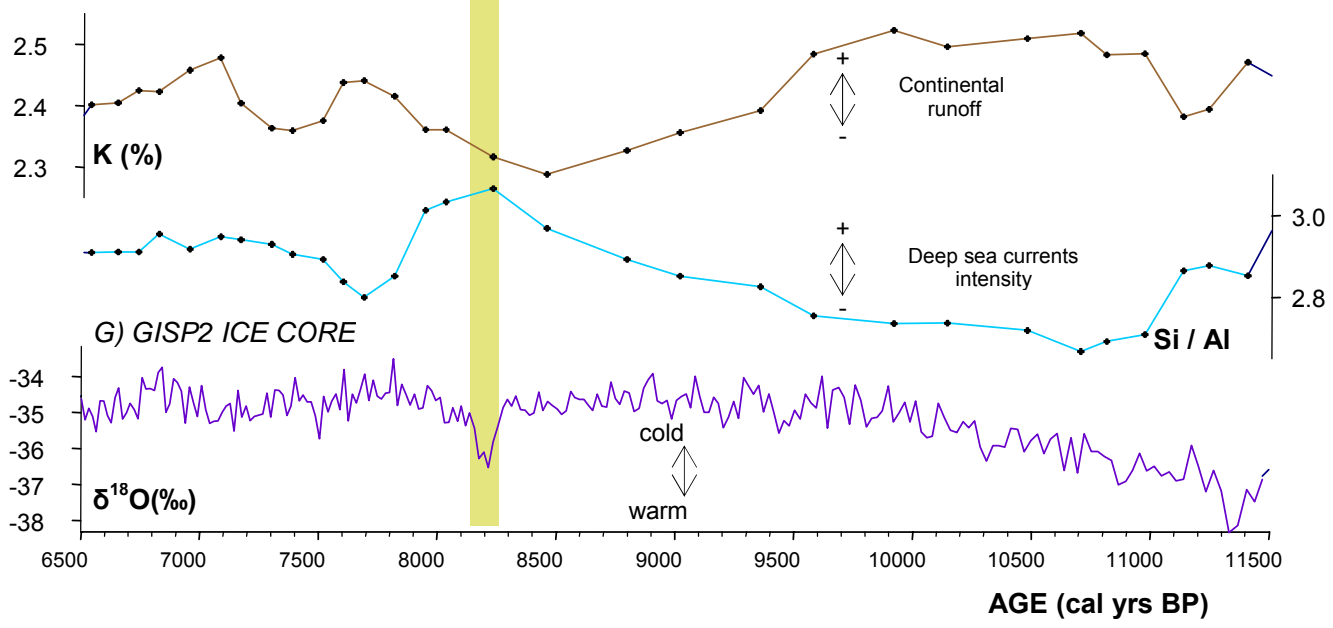


Additional information in attached link

Table 1. Early Holocene available radiocarbon dates (11-6.5 ky cal B.P.) from archaeological settlements of the North Ebro area (NE Spain).

Table 2. Early Holocene available radiocarbon dates (11-6.5 ky cal B.P.) from archaeological settlements of the South Ebro area (NE Spain). 
Table 1. Early Holocene available radiocarbon dates (11-6.5 ky cal B.P.) from archaeological settlements of the North Ebro area (NE Spain).

(0 = AD 1950). P (68\%). CalPal 2007, HULU curve.

Archaeology: Mag/AZ, Magdalenian/Azilian; Em, Epipalaeolithic microlaminar; MD, Mesolithic with Denticulates; MG, Mesolithic Geometric; NA, Ancient Neolithic; N, Neolithic

Dated material: B, Acorn; C/cc, Charcoal; Cl, Cerealia seed; H/hh, Bones (hum-humans, dom-animal)

\begin{tabular}{|c|c|c|c|c|c|c|c|}
\hline $\begin{array}{l}\text { Archaeological site } \\
\text { Level }\end{array}$ & Ref. Lab. & $\begin{array}{l}\text { Date } \\
\text { C14 }\end{array}$ & $\sigma$ & $\begin{array}{l}\text { cal } \\
\text { B.P. }\end{array}$ & $\sigma$ & Culture & Remain \\
\hline \multicolumn{8}{|l|}{ Abauntz } \\
\hline $2 \mathrm{r}$ & GrN-21010 & 5820 & 40 & 6620 & 60 & $\mathrm{~N}$ & $\mathrm{C}$ \\
\hline c & I-11537 & 6910 & 450 & 7770 & 430 & NA & hh \\
\hline d & Ly-1964 & 9530 & 300 & 10860 & 410 & Mag/Az & hh \\
\hline \multicolumn{8}{|l|}{ Peña de Marañón } \\
\hline d inf. & BM-2363 & 7890 & 120 & 8760 & 170 & MG & $\mathrm{H}$ \\
\hline \multicolumn{8}{|l|}{ Aizpea } \\
\hline III (b alt) & GrN-18421 & 6370 & 70 & 7310 & 80 & NA & hh \\
\hline II (b med/alt.) & GrA-799 & 6600 & 50 & 7500 & 50 & MG & $\mathrm{H}$ \\
\hline II (b med/alt.) & GrN-16622 & 6830 & 70 & 7680 & 70 & MG & hh \\
\hline I (b med.) & GrN-16621 & 7160 & 70 & 7990 & 70 & MG & hh \\
\hline I (b bas.) & GrN-16620 & 7790 & 70 & 8580 & 90 & MG & hh \\
\hline \multicolumn{8}{|l|}{ Atxoste } \\
\hline IIIb1 & GrN-9789 & 6220 & 60 & 7130 & 90 & NA & $\mathrm{H}$ \\
\hline IIIb2 & Sin datos & 6710 & 50 & 7580 & 50 & MG & $\mathrm{H}$ \\
\hline IIIb2 & GrA-13415 & 6940 & 40 & 7770 & 50 & MG & $\mathrm{H}$ \\
\hline IV & Sin datos & 6970 & 40 & 7810 & 60 & MG & $\mathrm{H}$ \\
\hline IIIb2 & Sin datos & 7140 & 50 & 7960 & 40 & MG & $\mathrm{H}$ \\
\hline IV & GrA-13418 & 7340 & 50 & 8150 & 80 & MG & $\mathrm{H}$ \\
\hline IV & GrA-13469 & 7480 & 50 & 8290 & 70 & MG & $\mathrm{H}$ \\
\hline V & GrA-13447 & 7810 & 40 & 8590 & 40 & MD & $\mathrm{H}$ \\
\hline V & GrA-13472 & 7830 & 50 & 8630 & 70 & MD & $\mathrm{H}$ \\
\hline V & GrA-13448 & 8030 & 50 & 8900 & 100 & MD & $\mathrm{H}$ \\
\hline IV & Sin datos & 8080 & 50 & 8980 & 110 & MD & $\mathrm{H}$ \\
\hline VI & GrA-15700 & 8510 & 80 & 9500 & 50 & MD & $\mathrm{H}$ \\
\hline VI & GrA-15699 & 8760 & 50 & 9770 & 110 & MD & $\mathrm{H}$ \\
\hline VI (Hogar) & GrA-13473 & 8840 & 50 & 9950 & 150 & MD & $\mathrm{H}$ \\
\hline E2 & Sin datos & 9510 & 150 & 10840 & 230 & Em & $\mathrm{H}$ \\
\hline VII & GrA-15858 & 9550 & 60 & 10910 & 140 & Em & $\mathrm{H}$ \\
\hline $\mathrm{E}$ & Sin datos & 9650 & 150 & 10970 & 210 & Em & $\mathrm{H}$ \\
\hline E2 & Sin datos & 9820 & 150 & 11270 & 300 & Em & $\mathrm{H}$ \\
\hline \multicolumn{8}{|l|}{ Balma Margineda } \\
\hline За (f1) & Ly-3288 & 6640 & 160 & 7520 & 140 & NA & $\mathrm{C}$ \\
\hline 3b (f3) & Ly-2839 & 6670 & 120 & 7550 & 90 & NA & $\mathrm{C}$ \\
\hline $3 / 4$ & Ly-3290 & 6820 & 170 & 7690 & 150 & NA & $\mathrm{C}$ \\
\hline 3b (f3) & Ly-3289 & 6850 & 160 & 7720 & 140 & NA & $\mathrm{C}$ \\
\hline 4 sup. & Ly-3291 & 8210 & 180 & 9130 & 250 & MD & $\mathrm{C}$ \\
\hline 4 sup. & Ly-2840 & 8390 & 150 & 9330 & 170 & MD & $\mathrm{C}$ \\
\hline 4 base & Ly-2841 & 8530 & 420 & 9560 & 540 & MD & $\mathrm{C}$ \\
\hline $4 / 5$ & Ly-3892 & 8850 & 120 & 9920 & 200 & MD & $\mathrm{C}$ \\
\hline $5 / 6$ & Ly-4402 & 8960 & 120 & 10030 & 180 & Em & $\mathrm{C}$ \\
\hline 4 base & Ly-4401 & 8970 & 120 & 10040 & 180 & MD & $\mathrm{C}$ \\
\hline
\end{tabular}




\begin{tabular}{|c|c|c|c|c|c|c|c|}
\hline 6 sup. & Ly-2842 & 9250 & 160 & 10480 & 200 & Em & C \\
\hline $6 \mathrm{~L}$ & Ly-3884 & 9900 & 110 & 11430 & 180 & $\mathrm{Em}$ & C \\
\hline \multicolumn{8}{|l|}{ Chaves } \\
\hline Ia & CSIC-381 & 6120 & 70 & 7020 & 110 & NA & C \\
\hline b (muerto) & GrA-26912 & 6230 & 45 & 7140 & 90 & NA & $\mathrm{H}$ \\
\hline Ia & CSIC-379 & 6230 & 70 & 7130 & 100 & NA & C \\
\hline Ia & GrN-13603 & 6260 & 100 & 7160 & 130 & NA & C \\
\hline Ia & GrN-13605 & 6330 & 70 & 7270 & 80 & NA & C \\
\hline Ia & GrN-13602 & 6330 & 90 & 7260 & 110 & NA & C \\
\hline Ia & GrA-28341 & 6380 & 40 & 7330 & 60 & NA & B \\
\hline Ib & CSIC-378 & 6460 & 70 & 7370 & 60 & NA & C \\
\hline Ib & GrN-13604 & 6490 & 40 & 7400 & 50 & NA & C \\
\hline Ib & GrN-12683 & 6650 & 80 & 7530 & 60 & NA & C \\
\hline Ib & GrN-12685 & 6770 & 70 & 7630 & 50 & NA & C \\
\hline \multicolumn{8}{|l|}{ Filador } \\
\hline 2 & AA-13411 & 8150 & 90 & 9130 & 120 & MD & C \\
\hline 2 & OxA-8658 & 8515 & 50 & 9510 & 30 & MD & C \\
\hline 7 & ICEN-495 & 9130 & 230 & 10280 & 330 & Em & C \\
\hline 4 & UBAR-284 & 9460 & 190 & 10770 & 280 & Em & C \\
\hline $5 / 6$ & AA-13412 & 9988 & 97 & 11520 & 190 & $\mathrm{Em}$ & C \\
\hline 7 & UBAR-257 & 9830 & 160 & 11290 & 310 & $\mathrm{Em}$ & C \\
\hline 4 & AA-8647 & 10020 & 80 & 11550 & 180 & Em & $\mathrm{H}$ \\
\hline \multicolumn{8}{|l|}{ Forcas I } \\
\hline VII & GrN-17784 & 9360 & 140 & 10630 & 230 & $\mathrm{Az} / \mathrm{Em}$ & $\mathrm{C}$ \\
\hline IX & GrN-17785 & 9715 & 75 & 11050 & 150 & $\mathrm{Az} / \mathrm{Em}$ & C \\
\hline \multicolumn{8}{|l|}{ Forcas II } \\
\hline VIII & GrN-22689 & 6680 & 190 & 7560 & 170 & NA & C \\
\hline VI & GrN-22688 & 6900 & 45 & 7740 & 50 & NA & C \\
\hline $\mathrm{V}$ & GrN-22687 & 6970 & 130 & 7810 & 120 & NA & C \\
\hline $\mathrm{V}$ & Beta 60773 & 6940 & 90 & 7790 & 90 & NA & C \\
\hline IV & Beta 59995 & 7090 & 340 & 7950 & 320 & MG & C \\
\hline II & GrN-22686 & 7240 & 40 & 8070 & 60 & MG & C \\
\hline Ib & CAMS-5354 & 8650 & 70 & 9650 & 90 & MD & $\mathrm{C}$ \\
\hline \multicolumn{8}{|l|}{ Fuente Hoz } \\
\hline II (lecho 16) & I-12084 & 6120 & 280 & 6970 & 310 & NA & C \\
\hline III (lecho 23) & I-12778 & 7140 & 120 & 7980 & 130 & MG & $\mathrm{C}$ \\
\hline III (lecho 21) & I-12083 & 7840 & 130 & 8710 & 190 & MG & $\mathrm{C}$ \\
\hline III (lecho 23) & I-13496 & 7880 & 120 & 8750 & 170 & MG & $\mathrm{C}$ \\
\hline III (lecho 28) & I-12985 & 8120 & 240 & 9020 & 310 & MD & C \\
\hline \multicolumn{8}{|l|}{ Huerto Raso } \\
\hline b (base) & GrA-21360 & 6310 & 60 & 7240 & 60 & NA & $\mathrm{C}$ \\
\hline \multicolumn{8}{|l|}{ Kanpanoste } \\
\hline Lanhs & GrN-22440 & 7620 & 70 & 8440 & 70 & MD & hh \\
\hline Lanhi (base) & GrN-22442 & 7920 & 100 & 8790 & 150 & MD & hh \\
\hline Lanhi (med.) & GrN-22441 & 8200 & 70 & 9180 & 110 & MD & hh \\
\hline \multicolumn{8}{|c|}{ Kanpanoste Goikoa } \\
\hline III & GrN-20214 & 6360 & 70 & 7300 & 80 & MG & hh \\
\hline III & GrN-20289 & 6550 & 260 & 7410 & 250 & MG & hh \\
\hline III inferior & GrN-20215 & 7620 & 80 & 8440 & 70 & MD & hh \\
\hline III inferior & GrN-20455 & 7860 & 330 & 8780 & 380 & MD & hh \\
\hline \multicolumn{8}{|l|}{ Legunova } \\
\hline 1 & GrA-24292 & 8200 & 50 & 9160 & 90 & MD & C \\
\hline 1 & GrA-22086 & 8250 & 60 & 9240 & 110 & MD & $\mathrm{C}$ \\
\hline 2 & GrA-24294 & 8800 & 60 & 9890 & 160 & MD & C \\
\hline
\end{tabular}




\begin{tabular}{|c|c|c|c|c|c|c|c|}
\hline \multicolumn{8}{|l|}{ Los Cascajos } \\
\hline Estructura 183 & Ua-16024 & 6185 & 45 & 7090 & 70 & NA & $\mathrm{H}$ \\
\hline Estructura 497 & Ua-24426 & 6230 & 50 & 7140 & 90 & NA & $\mathrm{H}$ \\
\hline Estructura 551 & Ua-24428 & 6435 & 45 & 7360 & 50 & NA & $\mathrm{C}$ \\
\hline \multicolumn{8}{|l|}{ Mendandia } \\
\hline I & GrN-22740 & 6440 & 40 & 7370 & 40 & NA & hh \\
\hline II & GrN-22741 & 6540 & 70 & 7450 & 70 & NA & hh \\
\hline III sup & GrN-22742 & 7180 & 45 & 8000 & 40 & NA & hh \\
\hline III sup & GrN-19658 & 7210 & 80 & 8050 & 80 & NA & hh \\
\hline III inf. & GrN-22743 & 7620 & 50 & 8440 & 50 & MG & hh \\
\hline IV & GrN-22745 & 7780 & 40 & 8550 & 50 & MD & hh \\
\hline IV & GrN-22744 & 7810 & 50 & 8600 & 60 & MD & hh \\
\hline V & GrA-6874 & 8500 & 60 & 9500 & 40 & $\mathrm{Em}$ & hh \\
\hline \multicolumn{8}{|l|}{ Molí del Salt } \\
\hline Sup & Beta-173335 & 8040 & 40 & 8910 & 100 & MD & $\mathrm{H}$ \\
\hline \multicolumn{8}{|l|}{ Moro de Olvena } \\
\hline Cámara superior & GrN-12119 & 6550 & 130 & 7440 & 110 & NA & $\mathrm{C}$ \\
\hline \multicolumn{8}{|l|}{ Paco Pons } \\
\hline 2 & GrA-19294 & 6010 & 45 & 6860 & 60 & NA & $\mathrm{C}$ \\
\hline 2 & GrA-19295 & 6045 & 45 & 6900 & 60 & NA & $\mathrm{C}$ \\
\hline \multicolumn{8}{|l|}{ Parco } \\
\hline IAB-40 & CSIC-279 & 5790 & 190 & 6630 & 220 & $\mathrm{~N}$ & hh \\
\hline EE1 & GrN-20058 & 6120 & 90 & 7010 & 130 & NA & $\mathrm{C}$ \\
\hline IAB-39 & CSIC-281 & 6170 & 70 & 7070 & 90 & NA & cC \\
\hline IAB-38 & CSIC-280 & 6450 & 230 & 7300 & 240 & NA & hh \\
\hline \multicolumn{8}{|l|}{ Paternanbidea } \\
\hline Enterramiento 2 (A) & GrA-13675 & 5960 & 40 & 6800 & 60 & NA & $\mathrm{H}$ \\
\hline Enterramiento 1 & GrA-13673 & 6090 & 40 & 6970 & 60 & NA & $\mathrm{H}$ \\
\hline \multicolumn{8}{|l|}{ Peña 14} \\
\hline $\mathrm{a}$ & GrN-25094 & 7660 & 90 & 8470 & 80 & MG & $\mathrm{C}$ \\
\hline $\mathrm{b}$ & GrN-25999 & 8000 & 80 & 8850 & 130 & MD & $\mathrm{C}$ \\
\hline $\mathrm{b}$ & GrN-25998 & 8000 & 90 & 8850 & 140 & MD & $\mathrm{C}$ \\
\hline b & GrN-25097 & 8340 & 130 & 9300 & 150 & $\mathrm{MD}$ & $\mathrm{C}$ \\
\hline b & GrN-25098 & 8780 & 110 & 9860 & 200 & MD & $\mathrm{C}$ \\
\hline \multicolumn{8}{|l|}{ Peña Larga } \\
\hline IV & I-14909 & 5830 & 110 & 6640 & 130 & NA & hh \\
\hline IV & I-15150 & 6150 & 230 & 7010 & 260 & NA & hh \\
\hline \multicolumn{8}{|l|}{ Puyascada } \\
\hline II & CSIC-384 & 5930 & 60 & 6770 & 80 & $\mathrm{~N}$ & $\mathrm{C}$ \\
\hline \multicolumn{8}{|l|}{ Riols } \\
\hline a1 & GrN-13976 & 6040 & 100 & 6920 & 140 & $\mathrm{~N}$ & C \\
\hline \multicolumn{8}{|l|}{ Zatoya } \\
\hline I & Ly-1397 & 6320 & 280 & 7160 & 290 & NA & hh \\
\hline $\mathrm{Ib}$ & Ly-1398 & 8150 & 220 & 9060 & 300 & $\mathrm{E}$ & $\mathrm{C}$ \\
\hline Ib & Ly-1457 & 8260 & 550 & 9270 & 670 & $\mathrm{E}$ & $\mathrm{C}$ \\
\hline
\end{tabular}


Table 2. Early Holocene available radiocarbon dates (11-6.5 ky cal B.P.) from archaeological settlements of the South Ebro area (NE Spain).

(0 = AD 1950). P (68\%). CalPal 2007, HULU curve.

Archaeology: Mag/AZ, Magdalenian/Azilian; Em, Epipalaeolithic microlaminar; MD, Mesolithic with Denticulates; MG, Mesolithic Geometric; NA, Ancient Neolithic; N, Neolithic

Dated material: B, Acorn; C/cc, Charcoal; Cl, Cerealia seed; H/hh, Bones (hum-humans, dom-animal)

\begin{tabular}{|c|c|c|c|c|c|c|c|}
\hline $\begin{array}{l}\text { Archaeological site } \\
\text { Level }\end{array}$ & Ref. Lab. & $\begin{array}{l}\text { date } \\
\text { C14 }\end{array}$ & $\sigma$ & cal B.P. & $\sigma$ & Culture & Remain \\
\hline \multicolumn{8}{|l|}{ Abrigo de Ángel 1} \\
\hline $10 \sup (<8 b)$ & GrA-21555 & 5820 & 110 & 6630 & 130 & NA & $\mathrm{H}$ \\
\hline 8c (U28) & GrA-27274 & 7435 & 45 & 8270 & 60 & MG & $\mathrm{C}$ \\
\hline U8 & Unknow & 7950 & 300 & 8870 & 360 & MG & Unknow \\
\hline 8c (U8-11) & GrA-27278 & 7955 & 45 & 8830 & 120 & MG & $\mathrm{C}$ \\
\hline 8d (U8 inf.) & GrN-15518 & 8060 & 270 & 8970 & 330 & MD & $\mathrm{C}$ \\
\hline U8 & Unknow & 8070 & 160 & 8970 & 240 & MD & Unknow \\
\hline 8d (U13) & GrN-15520 & 8150 & 170 & 9070 & 250 & MD & $\mathrm{C}$ \\
\hline 8d (U13) & GrN-15519 & 8210 & 210 & 9120 & 280 & MD & $\mathrm{C}$ \\
\hline $8 d$ & GrA-22826 & 8390 & 60 & 9400 & 70 & MD & $\mathrm{C}$ \\
\hline 9 (U13) & GrA-27275 & 9200 & 50 & 10380 & 80 & Unknow & $\mathrm{C}$ \\
\hline \multicolumn{8}{|l|}{ Abrigo de Ángel 2} \\
\hline $2 b$ & GrN-22836 & 8310 & 60 & 9310 & 100 & MD & $\mathrm{C}$ \\
\hline \multicolumn{8}{|c|}{ Botiqería dels Moros } \\
\hline 6 & GrA-13268 & 6040 & 50 & 6890 & 70 & NA & $\mathrm{H}$ \\
\hline 8 & GrA-13270 & 6240 & 50 & 7150 & 90 & NA & $\mathrm{H}$ \\
\hline 4 & GrA-13267 & 6830 & 50 & 7670 & 50 & EG/NA & $\mathrm{H}$ \\
\hline 2 & Ly-1198 & 7550 & 200 & 8370 & 210 & MG & cC \\
\hline 2 & GrA-13265 & 7600 & 50 & 8410 & 40 & MG & $\mathrm{H}$ \\
\hline \multicolumn{8}{|l|}{ Bruixes (C. de les) } \\
\hline III & Ly-4269 & 6460 & 140 & 7360 & 130 & NA & $\mathrm{C}$ \\
\hline \multicolumn{8}{|l|}{ Cabezo de la Cruz } \\
\hline UE 1351 & GrN-29134 & 7130 & 130 & 7960 & 140 & MG & $\mathrm{C}$ \\
\hline UE 1397 & GrN-29135 & 7150 & 70 & 7970 & 70 & MG & $\mathrm{C}$ \\
\hline \multicolumn{8}{|l|}{ Costalena } \\
\hline C3 (med/alt.) & GrA-10949 & 6310 & 170 & 7270 & 260 & NA & hh \\
\hline C3 (alt.) & GrN-14098 & 6420 & 250 & 7270 & 260 & NA & hh \\
\hline \multicolumn{8}{|l|}{ Cova del Vidre } \\
\hline II hogar & Beta-58934 & 6180 & 90 & 7080 & 120 & NA & $\mathrm{C}$ \\
\hline \multicolumn{8}{|l|}{ Cova Fosca } \\
\hline Z: -9 a-15 & Beta-148993 & 5820 & 40 & 6620 & 60 & NA & $\mathrm{C}$ \\
\hline Z: -34 a -48 & Beta-148996 & 5850 & 70 & 6660 & 90 & NA & $\mathrm{C}$ \\
\hline Z: -45 a-57 & Beta-148997 & 5870 & 80 & 6690 & 100 & NA & $\mathrm{C}$ \\
\hline Z: -15 a -41 & Beta-148994 & 5980 & 70 & 6830 & 90 & NA & $\mathrm{C}$ \\
\hline Z: -45 a-83 & Beta-148999 & 5980 & 70 & 6830 & 90 & NA & $\mathrm{C}$ \\
\hline Z: -118 a -120 & Beta-149005 & 6070 & 80 & 6960 & 130 & NA & $\mathrm{C}$ \\
\hline Z: -49 a -78 & Beta-149000 & 6080 & 80 & 6970 & 130 & NA & $\mathrm{C}$ \\
\hline $\mathrm{Z}:-120$ a -130 & Beta-149007 & 6130 & 60 & 7040 & 90 & NA & $\mathrm{C}$ \\
\hline Z: -65 a -79 & Beta-149001 & 6140 & 90 & 7030 & 120 & NA & $\mathrm{C}$ \\
\hline Z: -111 a -120 & Beta-149004 & 6150 & 70 & 7050 & 100 & NA & $\mathrm{C}$ \\
\hline Z: -119 & Beta-149006 & 6250 & 80 & 7150 & 110 & NA & C \\
\hline Z: -135 & Beta-149009 & 6390 & 40 & 7340 & 60 & NA & $\mathrm{C}$ \\
\hline
\end{tabular}




\begin{tabular}{|c|c|c|c|c|c|c|c|}
\hline Z: -180 & CSIC-356 & 7100 & 70 & 7920 & 70 & - & $\mathrm{C}$ \\
\hline Z: -182 & CSIC-357 & 7210 & 70 & 8050 & 80 & - & $\mathrm{C}$ \\
\hline Z: -184 & CSIC-353 & 7640 & 110 & 8450 & 100 & - & $\mathrm{C}$ \\
\hline Z: -270 & I-9868 & 8880 & 200 & 9950 & 250 & $\mathrm{Em} / \mathrm{MD}$ & $\mathrm{C}$ \\
\hline Z: -278 & I-11313 & 9460 & 160 & 10780 & 260 & Mag/AZ & $\mathrm{C}$ \\
\hline \multicolumn{8}{|c|}{ Cueva del Gato } \\
\hline S.I & GrA-22525 & 6240 & 50 & 7150 & 90 & $\mathrm{~N}$ & $\mathrm{C}$ \\
\hline \multicolumn{8}{|c|}{ Cueva Lóbrega } \\
\hline N. III & GrN-16110 & 6220 & 100 & 7120 & 120 & $\mathrm{~N}$ & hh \\
\hline \multicolumn{8}{|l|}{ Lámpara } \\
\hline Hoyo 1 & KIA 6789 & 6033 & 34 & 6880 & 50 & NA & hh (human) \\
\hline Ноyo 11 & KIA 21348 & 6125 & 33 & 7050 & 80 & NA & $\mathrm{H}$ \\
\hline Ноуо 1 & KIA 6790 & 6144 & 46 & 7060 & 80 & NA & H (human) \\
\hline Ноуо 9 & KIA 21352 & 6280 & 33 & 7220 & 40 & NA & $\mathrm{H}$ \\
\hline Hoyo 1 & UtC-13346 & 6280 & 50 & 7210 & 50 & NA & $\mathrm{Cl}$ \\
\hline Hoyo 1 & KIA 4780 & 6390 & 60 & 7330 & 60 & NA & $\mathrm{C}$ \\
\hline Ноуо 18 & KIA 21347 & 6407 & 34 & 7350 & 50 & NA & $\mathrm{H}$ \\
\hline Ноyo 13 & KIA 16571 & 6608 & 35 & 7510 & 40 & NA & $\mathrm{C}$ \\
\hline Ноyo 9 & KIA 16579 & 6610 & 32 & 7510 & 40 & NA & $\mathrm{C}$ \\
\hline Ноyо 13 & KIA 16574 & 6729 & 45 & 7600 & 40 & NA & $\mathrm{C}$ \\
\hline Ноуо 9 & KIA 16575 & 6744 & 33 & 7610 & 30 & NA & $\mathrm{C}$ \\
\hline Ноуо 13 & KIA 16566 & 6835 & 34 & 7670 & 30 & NA & $\mathrm{C}$ \\
\hline Ноуо 9 & KIA 21350 & 6871 & 33 & 7710 & 40 & NA & $\mathrm{H}$ \\
\hline Ноуо 18 & KIA 16577 & 6915 & 33 & 7750 & 40 & NA & $\mathrm{C}$ \\
\hline Ноуо 9 & KIA 16569 & 6920 & 50 & 7760 & 60 & NA & $\mathrm{C}$ \\
\hline Ноуо 18 & KIA 16570 & 6956 & 39 & 7790 & 50 & NA & $\mathrm{C}$ \\
\hline Ноyo 9 & KIA 16578 & 6975 & 32 & 7810 & 50 & NA & $\mathrm{C}$ \\
\hline Ноyo 9 & KIA 16580 & 6989 & 48 & 7830 & 70 & NA & $\mathrm{C}$ \\
\hline Ноуо 9 & KIA 16568 & 7000 & 32 & 7850 & 50 & NA & $\mathrm{C}$ \\
\hline Ноуо 18 & KIA 16581 & 7075 & 44 & 7910 & 50 & NA & $\mathrm{C}$ \\
\hline Ноyо 16 & KIA 16573 & 7108 & 34 & 7930 & 40 & NA & $\mathrm{C}$ \\
\hline Ноуо 9 & KIA 16576 & 7136 & 33 & 7970 & 30 & NA & $\mathrm{C}$ \\
\hline \multicolumn{8}{|l|}{ Los Baños } \\
\hline 2b3sup & GrA-21550 & 7350 & 60 & 8170 & 90 & MG & $\mathrm{C}$ \\
\hline 2b3inf & GrA-21551 & 7550 & 50 & 8360 & 40 & MG & C \\
\hline 2b3 general & GrN-24300 & 7570 & 100 & 8370 & 110 & MG & $\mathrm{C}$ \\
\hline $2 \mathrm{~b} 1$ & GrA-21552 & 7740 & 50 & 8520 & 60 & MG & C \\
\hline $2 \mathrm{~b} 1$ & GrN-24299 & 7840 & 100 & 8710 & 170 & MG & $\mathrm{C}$ \\
\hline 2b1 & GrA-21556 & 8040 & 50 & 8900 & 100 & MD/MG & $\mathrm{C}$ \\
\hline \multicolumn{8}{|l|}{ Mas Nou } \\
\hline 1 & Beta-136678 & 6560 & 130 & 7450 & 110 & NA & $\mathrm{C}$ \\
\hline $2 b$ & Beta-170713 & 6760 & 40 & 7620 & 30 & NA & $\mathrm{H}$ \\
\hline 1 & Beta-136676 & 6800 & 70 & 7650 & 60 & NA & $\mathrm{H}$ \\
\hline 1 & Beta-136677 & 6900 & 70 & 7750 & 70 & NA & $\mathrm{H}$ \\
\hline 3 & Beta-170715 & 6920 & 40 & 7760 & 50 & MG & $\mathrm{H}$ \\
\hline 3 & Beta-170714 & 6910 & 40 & 7750 & 50 & MG & $\mathrm{H}$ \\
\hline fosa & Unknown & 7010 & 40 & 7860 & 60 & MG & $\mathrm{H}$ \\
\hline \multicolumn{8}{|l|}{ Pontet } \\
\hline c inf. & GrN-14241 & 6370 & 70 & 7310 & 80 & NA & $\mathrm{C}$ \\
\hline $\mathrm{e}$ & GrN-16313 & 7340 & 70 & 8170 & 100 & MG & $\mathrm{C}$ \\
\hline \multicolumn{8}{|l|}{ Revilla } \\
\hline Estructura 8 & KIA 13943 & 5642 & 96 & 6450 & 110 & NA & $\mathrm{C}$ \\
\hline Estructura 4 & UtC-13348 & 6120 & 60 & 7030 & 100 & NA & $\mathrm{Cl}$ \\
\hline Estructura 12 & KIA 21353 & 6156 & 33 & 7070 & 70 & NA & H (dom.) \\
\hline
\end{tabular}




\begin{tabular}{|c|c|c|c|c|c|c|c|}
\hline Estructura 12 & KIA 21349 & 6158 & 31 & 7070 & 60 & NA & $\mathrm{H}$ \\
\hline Estructura 13 & KIA 21354 & 6177 & 31 & 7080 & 60 & NA & H (dom.) \\
\hline Estructura 2 & KIA 21346 & 6202 & 31 & 7100 & 60 & NA & H (dom.) \\
\hline Estructura 2 & UtC-13350 & 6210 & 60 & 7120 & 90 & NA & $\mathrm{Cl}$ \\
\hline Estructura 13 & KIA 21355 & 6230 & 30 & 7150 & 80 & NA & $\mathrm{H}$ \\
\hline Estructura 16 & UtC-13294 & 6240 & 50 & 7150 & 90 & NA & $\mathrm{Cl}$ \\
\hline Estructura 4 & KIA 21359 & 6245 & 34 & 7180 & 60 & NA & $\mathrm{H}$ \\
\hline Estructura 12 & UtC-13295 & 6250 & 50 & 7160 & 80 & NA & $\mathrm{Cl}$ \\
\hline Estructura 2 & UtC-13269 & 6250 & 50 & 7160 & 80 & NA & $\mathrm{Cl}$ \\
\hline Estructura 14 & KIA 21357 & 6271 & 31 & 7210 & 40 & NA & $\mathrm{H}$ \\
\hline Estructura 4 & KIA 21351 & 6289 & 31 & 7220 & 40 & NA & $\mathrm{H}$ \\
\hline Estructura 9 & UtC-13347 & 6313 & 48 & 7240 & 50 & NA & Cl. \\
\hline Estructura 4 & KIA 13936 & 6335 & 46 & 7270 & 60 & NA & $\mathrm{C}$ \\
\hline Estructura 4 & KIA 21356 & 6355 & 30 & 7290 & 30 & NA & H (dom.) \\
\hline Estructura 14 & KIA 21358 & 6365 & 36 & 7320 & 50 & NA & $\mathrm{H}$ \\
\hline Estructura 2 & KIA 13932 & 6385 & 35 & 7340 & 50 & NA & $\mathrm{C}$ \\
\hline Estructura 4 & KIA 13937 & 6405 & 36 & 7350 & 50 & NA & $\mathrm{C}$ \\
\hline Estructura 4 & KIA 13942 & 6415 & 36 & 7360 & 50 & NA & $\mathrm{C}$ \\
\hline Estructura 8 & KIA 13945 & 6446 & 39 & 7370 & 40 & NA & $\mathrm{C}$ \\
\hline Estructura 5 & KIA 13948 & 6449 & 37 & 7370 & 40 & NA & $\mathrm{C}$ \\
\hline Estructura 4 & KIA 13938 & 6449 & 42 & 7370 & 40 & NA & $\mathrm{C}$ \\
\hline Estructura 2 & KIA 13933 & 6468 & 40 & 7380 & 40 & NA & $\mathrm{C}$ \\
\hline Estructura 4 & KIA 13940 & 6568 & 37 & 7480 & 30 & NA & $\mathrm{C}$ \\
\hline Estructura 14 & KIA 13946 & 6691 & 48 & 7560 & 40 & NA & $\mathrm{C}$ \\
\hline Estructura 4 & KIA 13939 & 6755 & 57 & 7620 & 40 & NA & $\mathrm{C}$ \\
\hline Estructura 2 & KIA 13934 & 6772 & 47 & 7630 & 40 & NA & $\mathrm{C}$ \\
\hline Estructura 14 & KIA 13947 & 6809 & 37 & 7650 & 30 & NA & $\mathrm{C}$ \\
\hline Estructura 4 & KIA 13935 & 6983 & 45 & 7830 & 70 & NA & $\mathrm{C}$ \\
\hline Estructura 8 & KIA 13944 & 7014 & 37 & 7870 & 50 & NA & $\mathrm{C}$ \\
\hline Estructura 4 & KIA 13941 & 7165 & 37 & 7990 & 30 & NA & $\mathrm{C}$ \\
\hline \multicolumn{8}{|c|}{ Toros de Cantavieja } \\
\hline a1 & GrA-24791 & 5880 & 50 & 6710 & 50 & NA & $\mathrm{H}$ \\
\hline
\end{tabular}

